\title{
TOTAL KNEE SURGERY: OUR EXPERIENCE
}

\author{
Kamnar Viktor, Poposka Anastasika, Doksevska Bogojevska Milena \\ University Clinic for Orthopedic Surgery - Skopje, Republic of Macedonia
}

Primljen/Received 15. 05. 2017. god.

Abstract: Introduction: Revision knee arthroplasty is not a routine procedure and almost always it is a technically demanding operation. The paradigm in revision total knee arthroplasty is to achieve correct alignment of the components, maintenance of the joint space and ligament balance by providing a stable bone - implant fusion. Metaphyseal bone loss is a crucial problem in revision total knee arthroplasty. The bone loss is due to primary arthroplasty technical errors and design, or problematic removal of the implants.

Aim: The aim of this article is to present our experience on total knee revision surgery using tantalum metal cones as a structural bone graft substitute in total arthroplasty failure with gross metaphyseal bone loss categorized by the AORI classification, performed by a specific surgical technique and evaluated by the Knee Society Score (KSS).

Material and methods: From 2013 to 2016 at the University Clinic for Orthopedic Surgery in Skopje 21 patient has been treated with revision total knee arthroplasty. Twelve patients had type 1/type 2 bone defects according to AORI, and nine had type 3 bone defect. We used trabecular metal bone graft in type 3 bone defects. A special emphasis is placed on preoperative planning according to the classification system for ligament and soft tissue damage as well as the AORI classification in order to determine the quantity, location and extent of the bone loss. In our series in patients with type 3 deformities, trabecular metal augments were used. This material resembles the human trabecular bone by its cellular structure and elastic characteristics.

Results: Preoperatively, all the patients had Knee Society Score below 60, most of them were housebound, experiencing great pain and disability. After six months $95 \%$ were rated excellent, and on one year follow up, $89 \%$ were rated good or excellent (KSS score above 82 , mean score 81.5), 1 patient was marked as poor with a complication - dislocation of the prosthesis. In the follow up period there was no infection.
Prihvaćen/Accepted 20. 07. 2017. god.

Conclusion: Our results of revision knee arthroplasty by using the trabecular metal augments with at least a year of follow up are excellent according to the KSS compared to the other studies. The disadvantages of the study are mentioned and the need for further investigation is stressed.

Key words: Revision knee arthroplasty, metaphyseal bone loss, AORI classification, Knee Society scores, trabecular metal augments.

\section{INTRODUCTION}

Metaphyseal bone loss is a crucial problem in revision total knee arthroplasty. The bone loss is due to primary arthroplasty technical errors and design, or problematic removal of the implants. The paradigm in revision total knee arthroplasty is to achieve correct alignment of the components, maintenance of the joint space and ligament balance by providing a stable bone - implant fusion. The management of bone loss is completed by substituting it with bone cement, autologous spongy bone grafts, autologous structural graft fragments, modular metallic boosters or thicker polyethylene components. Nonetheless, the correct treatment for large defects remains undefined and homologous structural grafts, impacted spongy grafts or unconventional prostheses can be used (1). An invention that porous tantalum - trabecular metal booster, has an excellent biocompatibility, is safe to use, and has emerged its use in revision arthroplasty as a scaffold for osseous ingrowth i.e. as a structural bone graft substitute. This material also has the characteristic of mineral density preservation of the surrounding bone making it plausible for use in elderly osteoporotic bone. According to the Anderson Orthopedic Research Institute (AORI) classification, type 2-B and type 3 defects usually require large metal blocks, bulk structural allograft or highly porous metal cones, according to an algorithm later described. Tibial and femoral trabecular metal metaphyseal cones are a unique solution for large bone 
defects. These cones substitute bone loss, improve metaphyseal fixation, help correct malalignment, restore the joint line and may permit use of a shorter stem(2). The use of tantalum cones in revision arthroplasty literature has been shown to be associated with good clinical and radiological outcomes. Studies have shown that average Knee Society clinical scores (KSS) improve significantly postoperatively.

There are several reasons for total knee arthroplasty failure. The most prominent are: aseptic/septic loosening, acute trauma, unstable knee, angular, torsion deformity, pain, impaired patellar tracking, stiff knee, infection. The diagnosis is based on clinical, imaging and laboratory findings. Clinically, there is pain, instability of the knee, redness when septic loosening is suspected. We also ask if any traumatic event occured. The clinical findings show decreased range of motion, abnormality in the extensory apparatus. From the imaging techniques plain roentgenogram usually clears the picture, in some cases additional CT or MRI can be ordered. We use blood count, sedimentation rate and CRP from the laboratory findings, we send specimens from the knee aspirate for microbiology analysis. Sometimes we order scan with Tc99m.

The authors present retrospective case series of primary total knee arthroplasty failure that were treated with tantalum cones in a revision knee arthroplasty procedure in a tertiary academic institution under a single surgeon.

\section{AIM}

The aim of this article is to present our experience on total knee revision surgery using tantalum metal cones as a structural bone graft substitute in total arthroplasty failure with gross metaphyseal bone loss categorized by the AORI classification, performed by a specific surgical technique and evaluated by the Knee Society scores (KSS).

\section{MATERIAL AND METHODS}

From 2013 to 2016, at the University Clinic for Orthopedic Surgery in Skopje, 21 patient has been treated with revision total knee arthroplasty. Twelve patients had type 1/type 2 bone defects according to AORI, and nine had type 3 bone defect. We used trabecular metal bone graft in type 3 bone defects. The surgical procedures were performed at the University Clinic for Orthopedic Surgery in Skopje. The follow up was completed immediately postoperatively, on six months and a year after the procedure, by a clinical and radiological means using the KSS and osteo-integration signs. The patients were followed for at least a year after the procedure. In 5 patients of those with type 3 AORI defects the reason for revision was aseptic loosening, in the remaining 4 the procedure was second stage revision after an infection.

A special emphasis is placed on preoperative planning according to the classification system for ligament and soft tissue damage as well as the AORI classification (as shown in Figure 1) in order to determine the quantity, location and extent of the bone loss. In the AORI classification the femur and tibia are classified separately, as follows: type 1 - complete metaphyseal bone with small defects that would not compromise the stability of the revision implant (type F1-intact metaphyseal cortex of the femur, type T1-intact metaphyseal cortex of the tibia); type 2 - loss of spongy bone in the metaphyseal region, which could occur in one (A) or in two (B) femoral -type F2A or type F2B or tibial condyles-type T2A or type T2B; type 3-deficient metaphyseal bone, occasionally associated with detachment of the collateral ligaments (type F3-femoral metaphyseal defect, or type T3-tibial plateau defect).

Also, ligament stability and the extensor mechanism integrity is evaluated. The ligament status is classified as stable, absent PCL, absent LCL, absent MCL and absence of all ligaments around the knee.

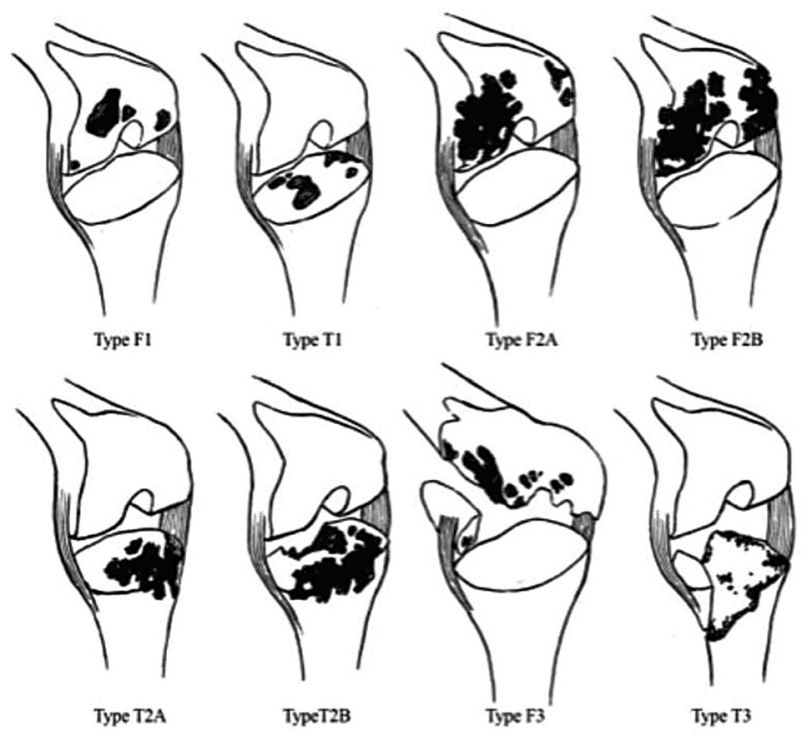

Figure 1. Anderson Orthopedic Research Institute (AORI) classification of bone defects in TKA

Usually, the real bone loss in situ surpasses the bone loss seen in the preoperative radiographs. All these steps lead to choosing the right approach for the revision, as well as obtaining the right implant, instruments, the need for bone transplants, or metal augments. In order to make the right choice of treatment we used the following algorithm (Figure 2).

Type 1 defects can be managed using cement, or in extraordinary cases, metal augments. Type 2 defects 


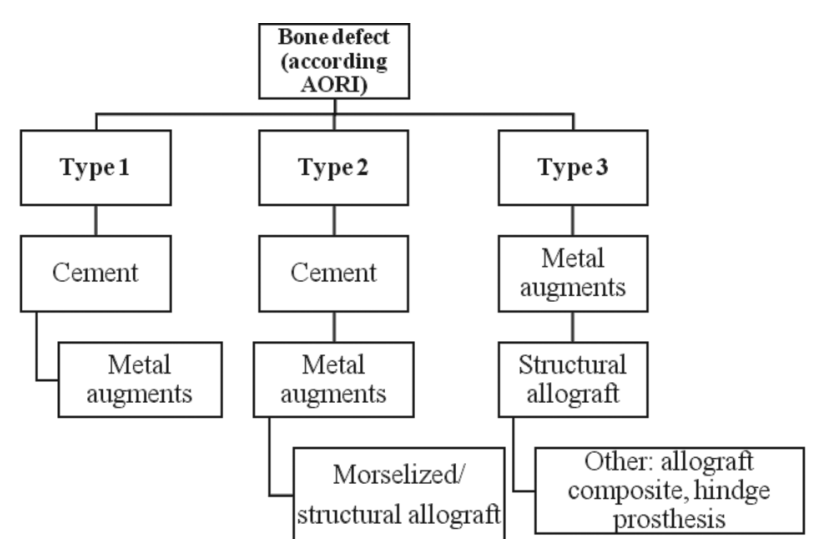

Figure 2. Algorithm for proper treatment according to AORI classification

can be worked out by metal augments, or morselized or structural allografts. In order to solve the problem with type 3 defects, metal augmentation, impact grafting, structural allograft, hinge or constrained condylar prosthesis is used.

In our series in patients with type 3 deformities, trabecular metal augments were used. This material resembles the human trabecular bone by its cellular structure and elastic characteristics. By approaching the mechanical and physical characteristics of the bone, the trabecular metal consists of $80 \%$ porosity, similar to the bone, enabling fast and broad bone infiltration.

Trabecular metal tibial and femoral cone augments enable secure structural bone substitute. The design allows filling the big cavitary bone defects and consequently preparing a stable platform for femoral and tibial components. The femoral cone augment is designed to contribute the reconstruction in rotation, and the asymmetric design follows the anatomic direction of the femoral bone during centralization. Eventual gaps between the porous surface and the host bone should be filled with morselized bone allograft, autograft or bone substitutes (3). Histological studies have shown low potential for bacterial adherence with greater leucocyte activation, reducing the risk of infections $(4,5)$.

The tibial trabecular metal cone is used to achieve stability in the construction of the proximal part of the calf where small to medium bone cavities are present. The tibial cone allows strengthening of the medular cavity of the tibia. Stable fixation is done by placing stem extensions for the femur and tibia.

\section{SURGICAL TECHNIQUE}

The exposure is medial parapatellar, using a central incision; whenever possible, the previous surgical incision is used (Figure 3). The subcutaneous tissue is thick dissected in order to maintain the vascularization and avoid ischemia leading to the medial parapatellar arthrotomy (Figure 4). At this point a swab culture, or

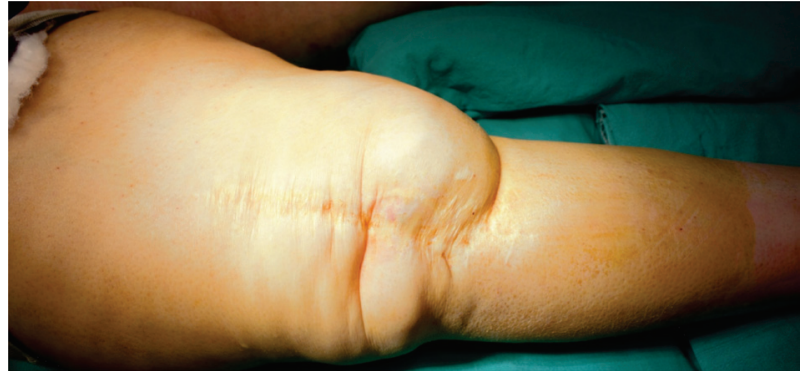

Figure 3. Scar tissue of the previous surgical interventions is used again in this patient

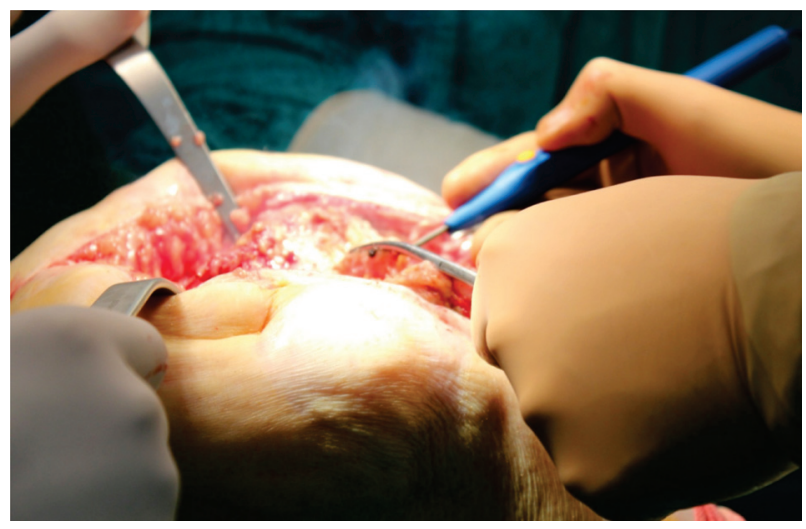

Figure 4. Thick dissected subcutaneous tissue

synovial fluid for microbiology assessment is obtained. Lateral parapatellar approach can be used in angular (valgus) deformities.

All the granulation tissue, necrotic tissue or evidence of infection should be removed, followed by wide debridement. In a case of infection evidence, the procedure is stopped and antibiotic impregnated polymethylmethacrylate spacer is introduced, the wound is closed and negative cultures are expected. Removal of the components can be difficult even if the reason for revision is component loosening. All soft tissue must be removed from the bone or the components. There are specific instruments for component removal that can be used in difficult extraction, or the removal can be achieved by using an osteotome. Sometimes it

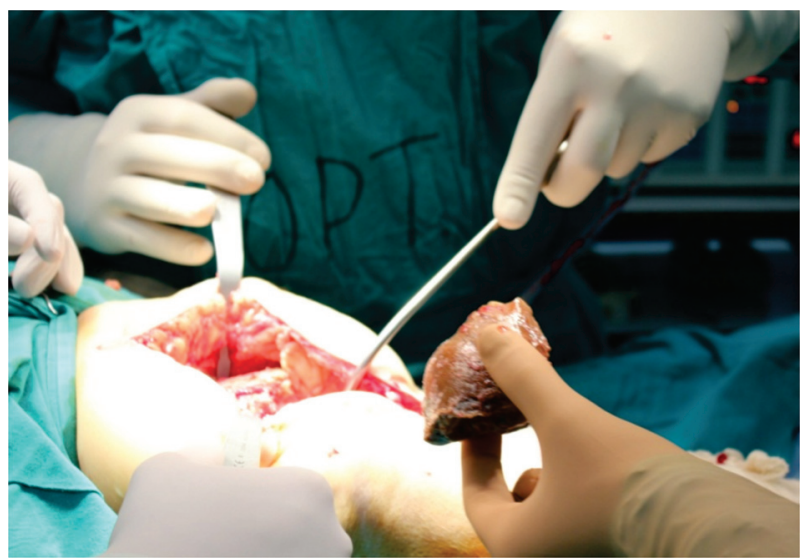

Figure 5. MMA spacer removal 


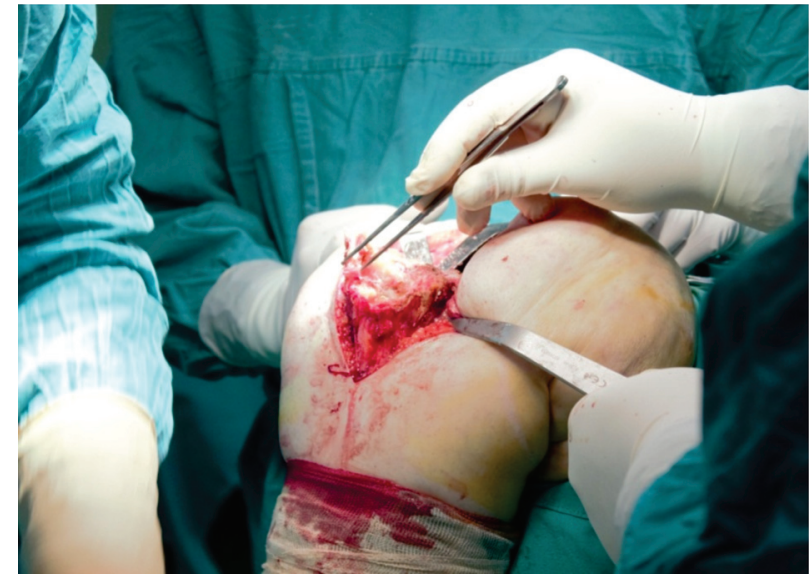

Figure 6. Tibia after the cement spacer removal, debridement of cement and granulation tissue

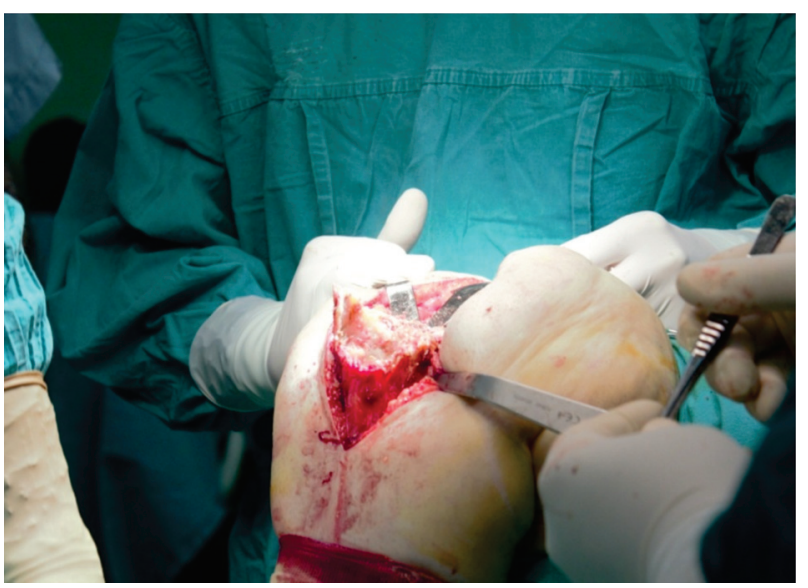

Figure 7. Tibia after the cement spacer removal, debridement of cement and granulation tissue

can be challenging to leave all the underlying bone intact which leads to iatrogenic bone loss. We usually remove the tibial component first and then the femoral component. A thorough removal of necrotic bone, debris, necrotic tissue and cement remaining is mandatory (Figure 5, 6 and 7).

Next step after we've reached a clear picture is the task to reconstruct the knee. Even though almost always it is not an easy duty, the imperative is to recreate an arthroplasty that is kinematically well adjusted. Reconstruction is approached using a three-step method: 1 . re-create the flat tibial surface, 2 . re-create the femur and rebuild the flexion space, and 3. rebuild the extension space (6). The cornerstone of rTKA is building a flat perpendicular tibial surface that will serve as basis for the arthroplasty. Therefore, recreating the tibial side to its original height by using the augments and subsequently placing the appropriate polyethylene insert leads to correct flexion and extension gaps (Figure 8 and 9).

On the femoral side it is very important not to undersize the femoral component, since usually there is posterior bone loss that can be easily overseen. An undersized

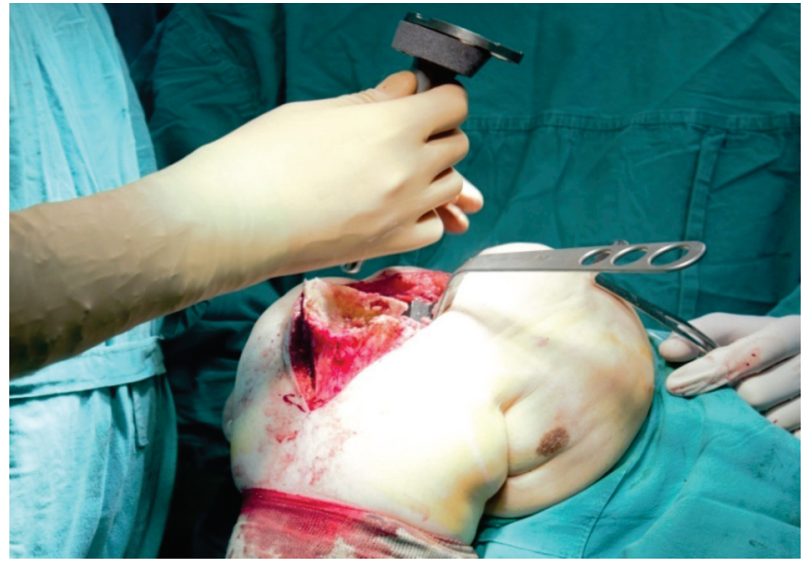

Figure 8. Placing the tibial augment and component

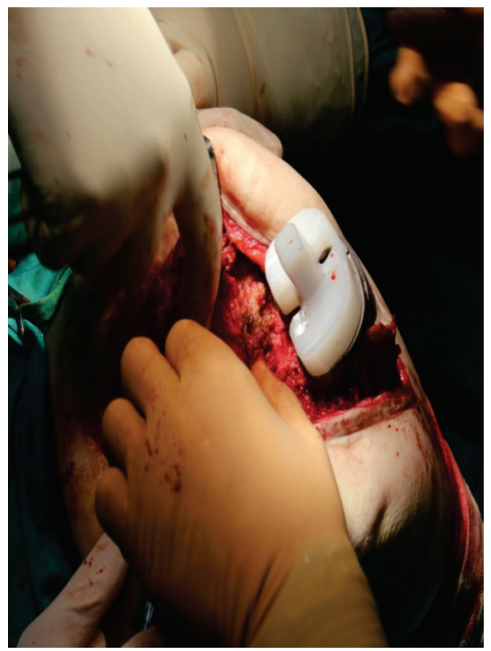

Figure 9. Tibial component in situ

component leads to failure to restore the posterior femoral offset and compromise flexion stability. Femur component rotation is adjusted towards the remaining femoral bone (the epicondyles or the tibial plateau if severe bone loss persists). The joint line is restored by distal femur positioning (Figure 10). The reconstruction is finalized by recreating the flexion and extension space. The flexion space is completed by inserting the thickest tibial polyethylene surface that fills the flexion space (Figure 11).

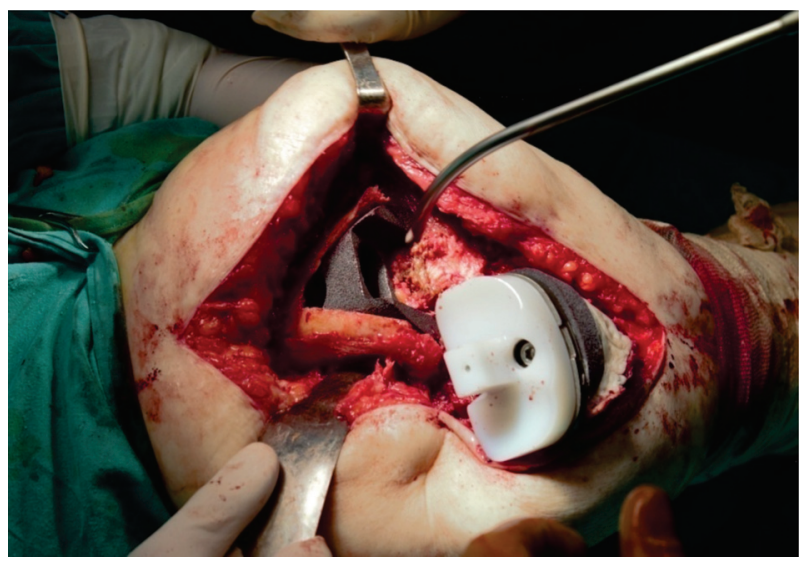

Figure 10. Femoral component placing 


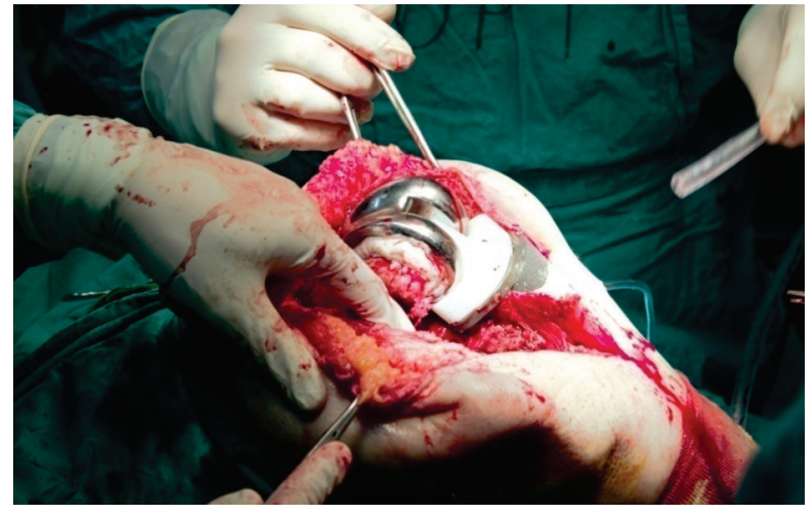

Figure 11. Joint line in flexion

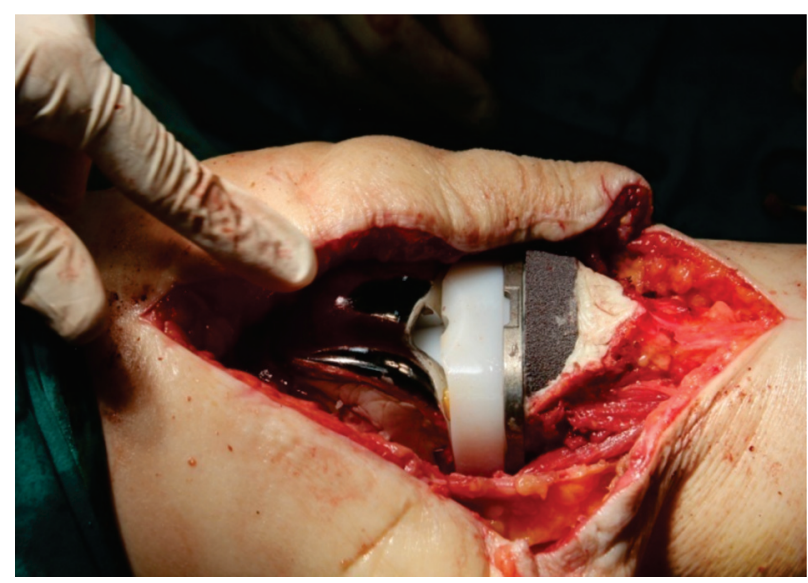

Figure 12. Joint line in extension

An attempt is made to extend the knee looking for stable and equal gaps. If we have achieved that, we expect to have a kinematically stable knee (Figure 12). Regarding design and devices, we used porous tantalum cones(Trabe$\operatorname{cular} \mathrm{Metal}^{\mathrm{TM}}$; Zimmer, Warsaw, IN, USA), Zimmer Legacy Constrained Condylar Knee (LCCK) or Zimmer Next Gen Rotating Hinge Knee (RHK).

\section{RESULTS}

We used the Knee Society score to evaluate the results preoperatively, on six months and a year after the procedure. We also used radiological means estimating theosteo-integration signs, obtaining radiologic images immediately postoperatively, on six months and after a year.
The Knee Society Score is a clinical rating system developed in 1989 and is consisted of an evaluation form subdivided in a knee score that rates only the knee joint itself and a functional score that rates the patient's ability to walk and climb stairs (7). The grading for the knee Society Score is: score of 80-100 as an excellent outcome, score 70-79 a good outcome, score 60-69 fair outcome and score below 60 as a poor outcome.

Preoperatively, all the patients had score below 60 , most of them were housebound, experiencing great pain and disability. After six months $95 \%$ were rated excellent, and on one year follow up, $89 \%$ were rated good or excellent (KSS score above 82, mean score $81.5), 1$ patient was marked as poor with a complication - dislocation of the prosthesis. In the follow up period there was no infection.

All patients were followed for at least a year (mean follow up of 28 months) (Table 1).

Radiographically we didn't encounter subsidence or signs of failure in all the images (Figures 13, 14, 15). No radiolucencies were identified on the bone-tanta-
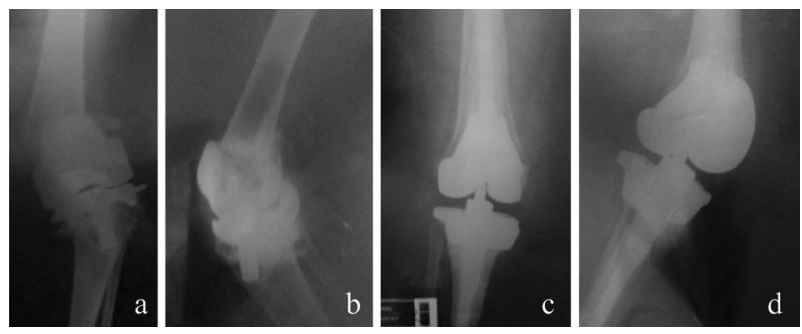

Figure 13. Case 1: a) and b) preoperative radiographs; c) and d) postoperative radiographs
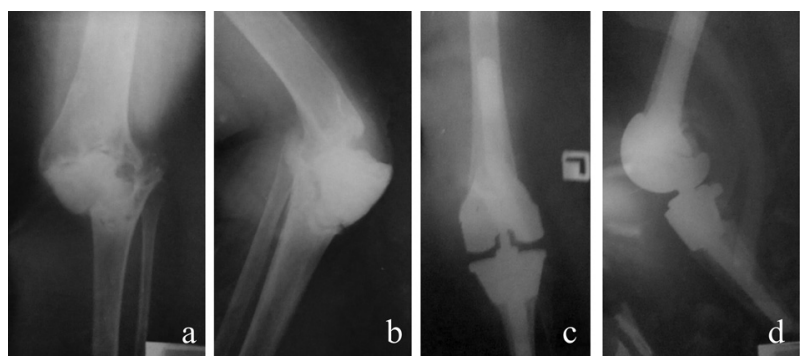

Figure 14. Case 2: a) and b) preoperative radiographs; c) and d) postoperative radiographs

Table 1. Revision total knee arthroplasty results in patients with type 3 defects according AORI

\begin{tabular}{|c|c|c|c|c|c|}
\hline Case & Age & Gender & $\begin{array}{c}\text { Follow-up } \\
\text { (months) }\end{array}$ & $\begin{array}{c}\text { Stage by AORI } \\
\text { classification }\end{array}$ & $\begin{array}{c}\text { Postoperative } \\
\text { KSS }\end{array}$ \\
\hline 1 & 79 & F & 48 & F2B T3 & 79 \\
\hline 2 & 75 & F & 44 & F3 T3 & 85 \\
\hline 3 & 69 & M & 39 & F3 T2A & 89 \\
\hline 4 & 79 & F & 32 & F3 T3 & 55 \\
\hline 5 & 66 & F & 27 & F2A T3 & 83 \\
\hline 6 & 72 & F & 24 & F3 T3 & 84 \\
\hline 7 & 77 & M & 18 & F2A T3 & 87 \\
\hline 8 & 69 & M & 13 & F3 T3 & 90 \\
\hline 9 & 70 & F & 12 & F2B T3 & 82 \\
\hline
\end{tabular}



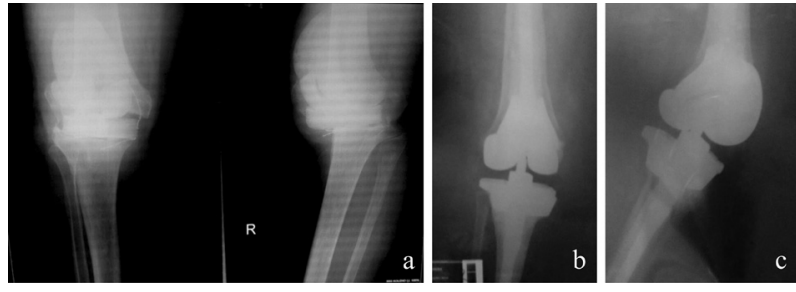

Figure 15. Case 3: a) preoperative radiographs, b) and c) postoperative radiographs

lum interface and there was no migration of the femoral or tibial components.

\section{DISCUSSION AND CONCLUSION}

Revision knee arthroplasty is not a routine procedure and almost always it is a technically demanding operation. The instruments are not as helpful as they are in the primary knee arthroplasty. The techniques for revision arthroplasty evolve continuously. Having that in mind it is hard to present consistent results since material improvement leads to better outcome (8).

Bone defects are challenge during the rTKA and there are many treatment options, that include cement filling, cement with augmentation, metal augmentation, moselised and structural bone grafts, and tantalum. Which modality will be used depends on the location and size of the bone defect, the bone quality, the surgeon's preference and material availability (9).

First published work on trabecular metal use in rTKA is the one of Radnay and Scuderi in 2006 (10). Their pioneer work with average 10 months follow up showed the good prognosis of the use in this metal in rTKA.

In their review article for treatment options for rTKA, Qiu and al. systematically show the advantages and disadvantages of all the treatment possibilities. The advantages of trabecular metal are its biocompatibility and bioactivity, the low modulus of elasticity, as well as the high frictional characteristics and a high volumetric porosity. The disadvantages are that it's not a popular choice, the lack long-term follow-up and its cost (11).

Fosco and al. in their work from 2012 stress that in the elderly, bone loss should be accomplished using artificial materials, while in younger patients, therapy should be addressed to regeneration of new bone as a foundation for future revision procedures. So that, an ideal bone substitute should possess an osteogenic, osteoinductive and osteoconductive potential (12). They also say that although the results of metaphyseal metal implants are promising, concerns still exist regarding stress shielding and difficulty of their removal. The other modalities of treatment as structuralallografts and tumor megaprostheses during revision kneearthroplasty have encouraging midterm results, but there is a high number of complications such as infection, graft resorption, nonunion, failure of graft incorporation, potential disease transmission, aseptic loosening and periprosthetic fracture $(13,14,15)$.

Even though these types of operations are used for many years in the USA and Europe for about a decade, these are the first reported cases from our country that have undergone this demanding operation with implantation of expensive materials. Therefore, we present the clinical outcomes according the Knee Society score as well as radiologic findings for osteointegration.

We are aware of the limitations of this study. The patient cohort is relatively small, but not much smaller than cohorts of the previous studies, regarding the number of patients migrating in our institution $(16,17$, 18). Next, the mean follow up of 28 months is short, the patients need to be followed longer in order to get the right picture of the durability of these implants. Even though we have protocol for radiologic investigation, and that is standing AP and lateral views, the quality of the radiographs differs depending on the technician experience and X-ray paper and machine quality.

The results of our study can be compared and are similar to those reported by De Martino and al. (19), Meneghini et al. (18) and Long and Scuderi (17) having an unquestionable osteointegration of the cones and similar percent for the need of reoperation. The increase of the Knee Society score in terms of pre and postoperative numbers is similar to other studies $(2,16,20)$.

The use of tantalum cones in our short term study, as well as several mid-term studies have shown to be successful, adding an option for favorable outcome in these highly demanding interventions and it has become a cornerstone in the treatment of bone loss in contemporary revision surgery. Waiting for studies with longer follow up, we remain close to this technique especially in elderly patients with low demands.

\section{Abbreviations}

AORI classification - Anderson Orthopedic Research Institute classification

KSS - Knee Society Score

rTKA — revision total knee arthroplasty

PCL - posterior cruciate ligament

LCL - lateral collateral ligament

MCL - medial collateral ligament

\section{CONFLICT OF INTEREST}

The authors declare that there is no conflict of interest.

\section{Licensing}

This work is licensed under a Creative Commons Attribution 4.0 International (CC BY 4.0) License. 


\title{
Sažetak
}

\section{REVIZIONA ARTROPLASTIKA KOLENA: NAŠE ISKUSTVO}

\author{
Kamnar Viktor, Poposka Anastasika, Doksevska Bogojevska Milena
}

Univerzitetska Klinika za Ortopediju u Skoplju, Republika Makedonija

Uvod: Reviziona artroplastika kolena nije rutinska procedura i uglavnom uvek je tehnički zahtevna operacija. Cilj revizione totalne artroplastike kolena je da se postigne tačno poravnjanje komponenti, očuvanje prostora zgloba i balans ligamenata obezbeđujući stabilnu kost-implant fuziju. Metafizealni gubitak kosti je krucijalni problem kod revizione totalne artroplastike kosti. Gubitak kosti je posledica tehničke greške i dizajna primarne artroplastike ili problematičnog uklanjanja implanata.

Cilj: Cilj ovog rada je da prikaže naše iskustvo sa revizionom hirurgijom kolena nakon neuspele totalne artroplastike, sa značajnim metafizealnim gubitkom kosti kategorisanim AORI klasifikacijom, uz upotrebu tantal konusa i specifične hirurške tehnike, i evaluaciju pomoću skora udruženja za koleno (KSS-Knee Society Score).

Materijal i Metode: Od 2013. do 2016. godine, na Univerzitetskoj Klinici za Ortopediju u Skoplju, 21 pacijent je podvrgnut revizionoj totalnoj artroplastici kolena. Dvanaest pacijenata je imalo tip 1/tip2 defekt kosti prema AORI klasifikaciji, 9 je imalo tip 3. Poseban akcenat je stavljan na preoperativno planiranje na osnovu klasifikacije povreda ligamenata i mekih tkiva, uključujući i AORI klasifikaciju , s ciljem da se utvrdi

\section{REFERENCES}

1. Mozella Ade P, Olivero RR, Alexandre H, Cobra AB. Use of a trabecular metal cone made of tantalum, to treat bone defects during revision knee arthroplasty. Rev Bras Ortop. 2014; 49(3): 245-51.

2. Lachiewicz PF, Watters TS. Porous metal metaphyseal cones for severe bone loss: when only metal will do. Bone Joint J. 2014; 96-B(11 Supple A): 118-21.

3. De Martino I, De Santis V, Sculco PK, D’Apolito R, Assini JB, Gasparini G. Tantalum cones provide durable mid-term fixation in revision TKA. Clin Orthop Relat Res. 2015; 473(10): 3176-82.

4. Schildhauer TA, Robie B, Muhr G, Koller M. Bacterial adherence to tantalum versus commonly used orthopedic metallic implant materials. J Orthop Trauma.2006; 20(7): 476-84.

5. Schildhauer TA, Peter E, Muhr G, Koller M. Activation of human leukocytes on tantalum trabecular metal in comparison to commonly used orthopedic metal implant materials. J Biomed Mater Res Part A. 2009; 88(2): 332-41.

6. W. Norman Scott, Insall and Scott Surgery of the Knee. $5^{\text {th }}$ Ed. Churchill Livingstone, 2011.

7. Insall JN, Dorr LD, Scott RD, Scott WN. Rationale of the Knee Society clinical rating system. Clin Orthop Relat Res. 1989; 248: 13-4. kvantitet, lokalizacija i stepen gubitka kosti. Koristili smo trabekularni metal kao koštani graft kod defekta kosti tip 3. Ovo je biomaterijal koji je po svojoj strukturi i karakteristikama elasticiteta najsličniji strukturi trabekularne kosti.

Rezultati: Preoperativno, svi pacijenti su imali KSS ispod 60,većina ih je bila vezana za kuću, osećala jake bolove i imala značajan stepen nesposobnosti. Posle šest meseci kod $95 \%$ operisanih stanje je okarakterisano kao odlično, a posle godinu dana praćenja kod $85 \%$ pacijenata stanje je okarakterisano kao dobro ili odlično (KSS iznad 82, srednja vrednost skora 81,5), stanje kod 1 pacijenta je okarakterisano kao loše, sa dislokacijom proteze kao komplikacijom. U toku perioda praćenja nije bilo infekcija.

Zaključak: Naši rezultati revizione artroplastike kolena sa upotrebom trabekularnog metala, nakon godinu dana praćenja, okarakterisani su kao odlični prema KSS skoru u odnosu na druge studije. Nedostaci studije su opisani i naglašena je potreba za daljim istraživanjem.

Ključne reči: reviziona artroplastika kolena, metafizealni gubitak kosti, AORI klasifikacija, skor udruženja za koleno, trabekularni metal.

8. Bertin KC, Freeman MA, Samuelson KM, Ratcliffe SS, Todd RC. Stemmed revision arthroplasty for aseptic loosening of total knee replacement. J Bone Joint Surg Br. 1985; 67(2): 242-8.

9. Peters CL, Erickson JA, Gililland JM. Clinical and radiographic results of 184 consecutive revision total knee arthroplasties placed with modular cementless stems. J Arthroplasty. 2009; 24(6 Suppl): 48-53.

10. Radnay CS, Scuderi GR. Management of bone loss: augments, cones, offset stems. Clin Orthop Relat Res. 2006; 446: 83-92.

11. Qiu YY, Yan CH, Chiu KY, Ng FY. Review article: Treatments for bone loss in revision total knee arthroplasty. J OrthopSurg (Hong Kong). 2012; 20(1): 78-86.

12. Fosco M, Ayad RB, Amendola L, Dallari D, Tigani D. Management of bone loss in primary and revision knee replacement surgery. In Recent Advances in Arthroplasty 2012. InTech.

13. Bauman RD, Lewallen DG, Hanssen AD. Limitations of structural allograft in revision total knee arthroplasty. Clin Orthop Relat Res. 2009; 467(3): 818-24.

14. Pour AE, Parvizi J, Slenker N, Purtill JJ, Sharkey PF. Rotating hinged total knee replacement: use with caution. J Bone JointSurg Am. 2007; 89(8): 1735-41.

15. Hockman DE, Ammeen D, Engh GA. Augments and allografts inrevision total knee arthroplasty: usage and outcome 
using onemodular revision prosthesis. J Arthroplasty. 2005; 20(1): 35-41.

16. Derome P, Sternheim A, Backstein D, Malo M.Treatment of large bone defects with trabecular metal cones in revision total knee arthroplasty: short term clinical and radiographic outcomes. J Arthroplasty. 2104; 29 (1): 122-6.

17. Long WJ, Scuderi GR. Porous tantalum cones for large metaphyseal tibial defects in revision total knee arthroplasty: a minimum 2 years follow up.J Arthroplasty. 2009: 24(7): 1086-92.

18. Meneghini RM, Lewallen DG, Hanssen AD. Use of porous tantalum metaphyseal cones for severe tibial bone loss during revision total knee replacement. J Bone Joint Surg Am. 2008; 90(1): 78-84.

19. De Martino I, De Santis V, Sculco PK, D’Apolito R, Assini JB, Gasparini G. Tantalum cones provide durable mid-term fixation in revision TKA. Clin Orthop Relat Res. 2015; 473(10): 3176-82.

20. Howard JL, Kudera J, Lewallen DG, Hanssen AD. Early results of the use of tantalum femoral cones for revision total knee arthroplasty. J Bone Joint Surg Am. 2011; 93(5): 478-84.

\section{Correspondence to / Autor za korespondenciju}

Ass. Dr. Viktor Kamnar, dr. sci

University Clinic for Orthopaedic Surgery

Vodnjanska 17, 1000 Skopje, Macedonia

Tel.: ++38975 443779

E-mail: kamnar25@gmail.com 